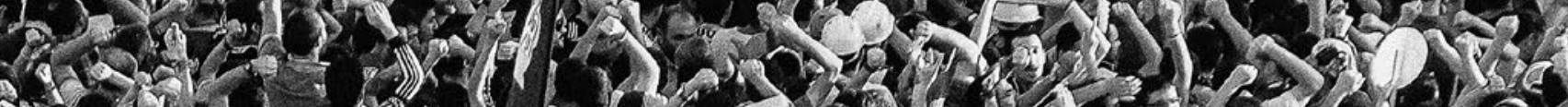

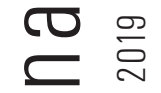

高

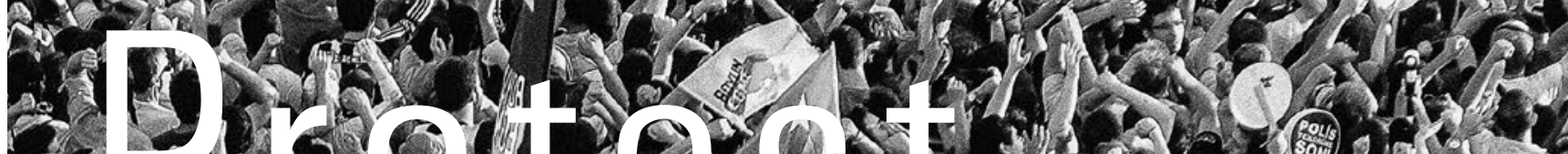
- D 20 Can

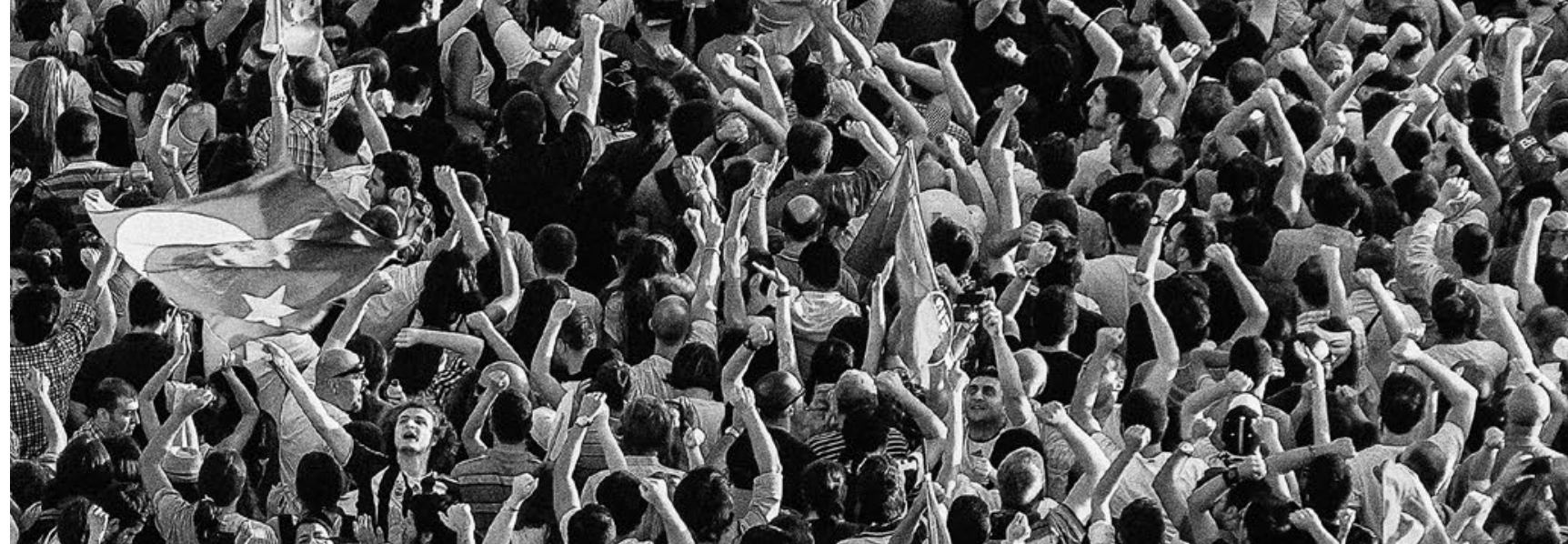
(2)

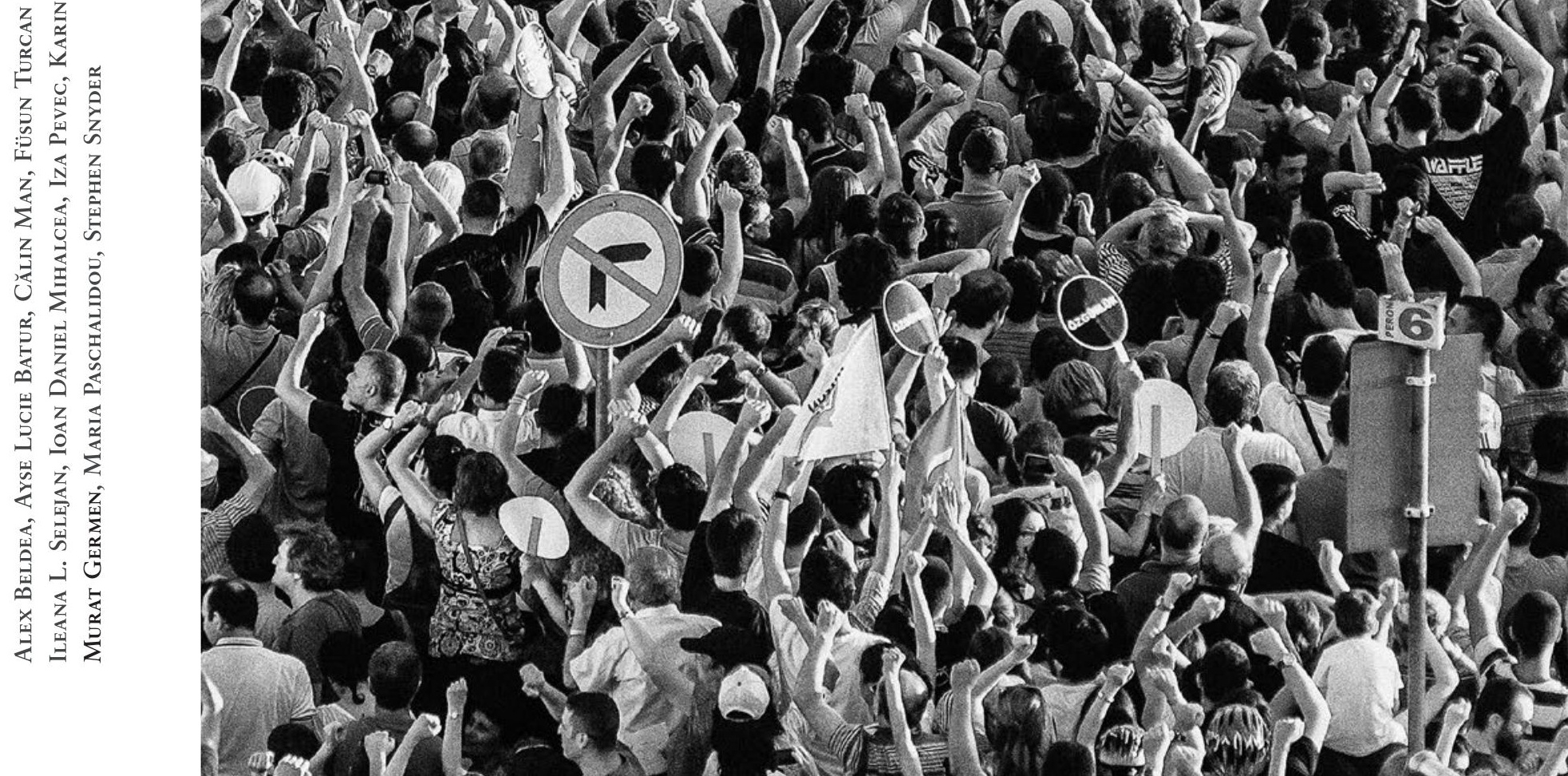




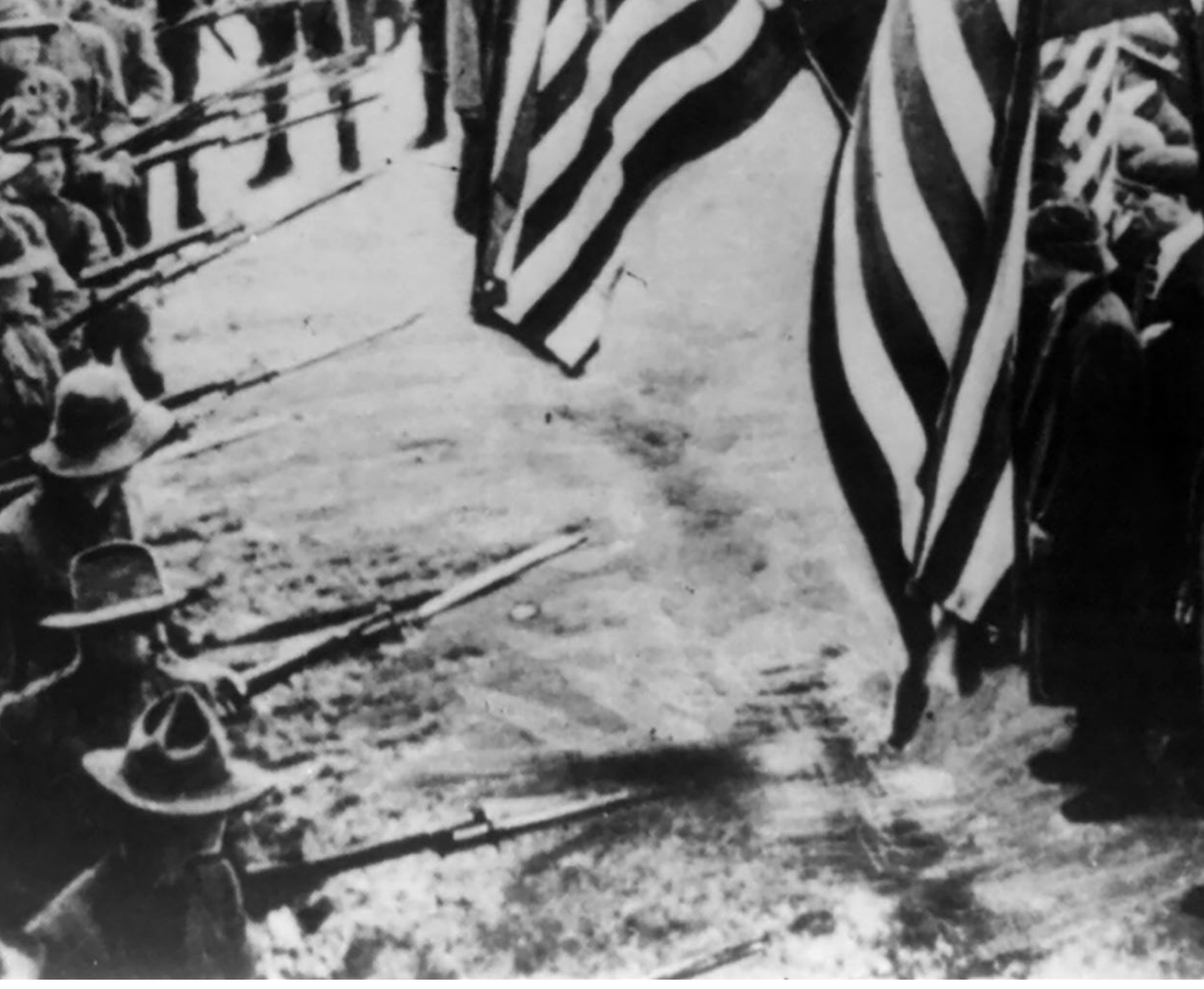

\section{Protest}

Throughout THE TWENTIETH CeNTURY, Political AND SOCial Protests have become one of the most widespread forms of political contention and collective social action and are to an ever greater extent shaping the contours of public debate since the beginning of the new millennium. Unsurprisingly, within the present milieu of crumbling social consensus, growing political polarization and legitimacy crisis of key institutions of modern state, various forms of political and social protests are on the rise. Visual capabilities of new communication technologies have not only significantly changed the nature and extent of documentation and challenged the institutionalized mediation and communication, but also contributed to codification, even standardization of the visual representations of protests. Strained between symbols (e.g. tank man), metaphors (e.g. protesters giving flowers to police/military) and visual clichés (e.g. rock-throwing masked protester), images of protests and protesters play an important role in struggles over interpretation of the events, legitimacy of protester's demands and their status as either citizens, crowds, "the people" or mobs. Moreover, protest visuals are not simply part of representation of events; they are increasingly becoming tools of political mobilization, resistance and even modes of protesting themselves through image-based activism, documentation and archiving projects and more. 
4 If There is No Community, There is No City • Interview with Murat Germen • Iza Pevec

14 The Best Weapon is Camera • Interview with Gabriel Uchida • Louise M. Hisayasu

26 Transvaluation and Aesthetic Displacement - Gezi Park and the Power of Art • Stephen Snyder

31 Protest, Symbol, and Web Browser - Collected and edited by Nataša ilec

44 Semiotics of the Protest - Maria Paschalidou

50 Actions Situations Possible Scenarios • Ileana L. Selejan

56 Digital Intifada • Photography as Protest in Palestine • Alex Beldea

62 Protest in the Photo Essay • Following Tradition or Breaking New Ground? • Karin Becker

68 An Example of a Diachronic Imagination from the Gezi Uprising • Ayse Lucie Batur

76 Photographs of the Miners' Raids - Reworking Images of the Past and Negotiating the Present $\bullet$ Ioan Daniel Mihalcea 


\section{Actions \\ Situations \\ Possible \\ Scenarios}

Ileana L. Selejan

\section{Memories of an Imaginary Wall}

I grew up behind the so-called "iron curtain," an impermeable entity the presence of which I was only aware of on a perceptive, intuitive level. I imagined the wall resembled the walls that were familiar to me, the type that could be seen in our neighbourhood, the type of walls my friends from the block and I would climb. In the nineties, the block would come to signify a greater sense of community, not merely through its presentation in contemporary American music, but also through its monumental perplexity during the years I lived in New York City. I found a lot of common ground between my "post-industrial sublime" and architectural outlines that exemplified the systemic oppression of racialized communities. However, as a child, I imagined the boundary that separated us from the West in a playful way, like the Great Wall of China, a dragon's spine stretching out for miles, sliding up and down the map in slow motion.

Years later, as I was reminiscing with my parents, I learnt about their first trip to East Berlin in circa 1986. They told me that on our side you could only come as close as fifty meters or so to the heavily guarded Brandenburg gate. "You knew," my father said, "that if you came closer, they will shoot." Hardly enough space to move, certainly not enough to attempt anything, even as a joke. The situation appeared to have been lighter on the other side, where they imagined, as did I, people had more fun, more freedom, more possessions, more everything. "You could see people peeking over to our side, waving, whistling, calling out to us." Us. And them. And after all we're only ordinary men (Pink Floyd, 1973). The recounted episode only helped affirm the stereotype that would echo in my mind: but we had a tighter community, a greater sense of purpose, we were much poorer but happier, sheltered from the excess of capitalism ... all I remember from my parents' trip is that they brought back candy, colourful bags of different types of candy that they laid across my bed.

The East, the Block, Berlin, the possibility of change. "I never thought it would come to an end, but when it was about to, I was willing to participate," my mother told me. Die Wende, as it was referred to in German, the turn. It swept through the Eastern Block, eventually precipitating the Romanian revolution of December 1989. In my mind's eye, my parents' memories of Berlin turned into postcards. I've searched for ways to access these images, to reconcile my experience of being in Berlin as a student with theirs, but it was almost impossible to find an overlap. The wall was still within living memory, a site of concurrent total closure and selective passage, one that had altered the lives and routines of millions. A great contrast to the lightness with which tourists now stroll through the Brandenburg gates. One afternoon, as I was headed for the park, I rode past them on my bicycle. That summer I visited an apartment that overlooked a section of the wall. It crossed through the building's backyard, a white line across a patch of green, hardly discernible amongst the 
Călin Man's interventions were

created to accompany this text,

placing the photographs referenced

within the text in dialogue with the

pictures taken in the city of Arad

Romania, between 1980 and 1990

Only one photograph depicts the

events that took place during the

1989 revolution.
Figure 1
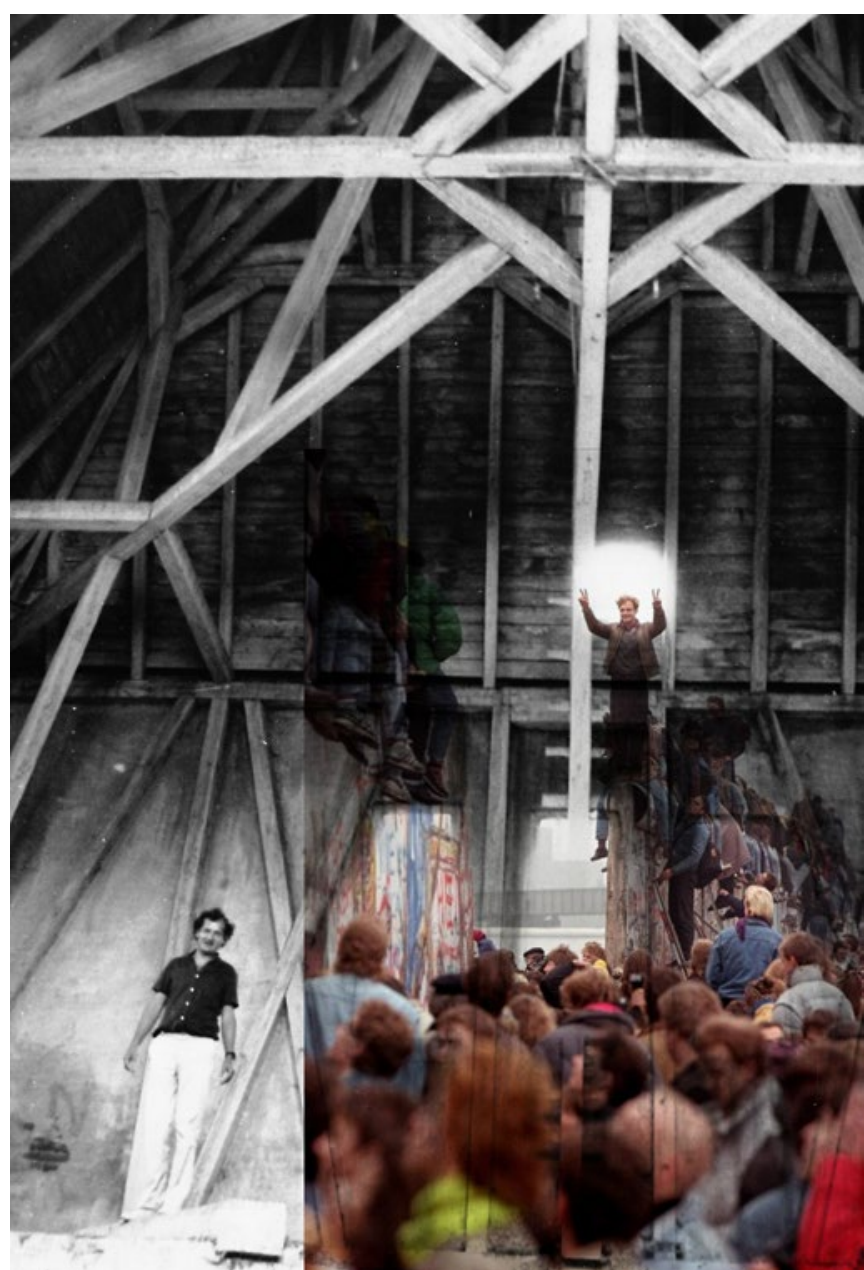

Figure 2

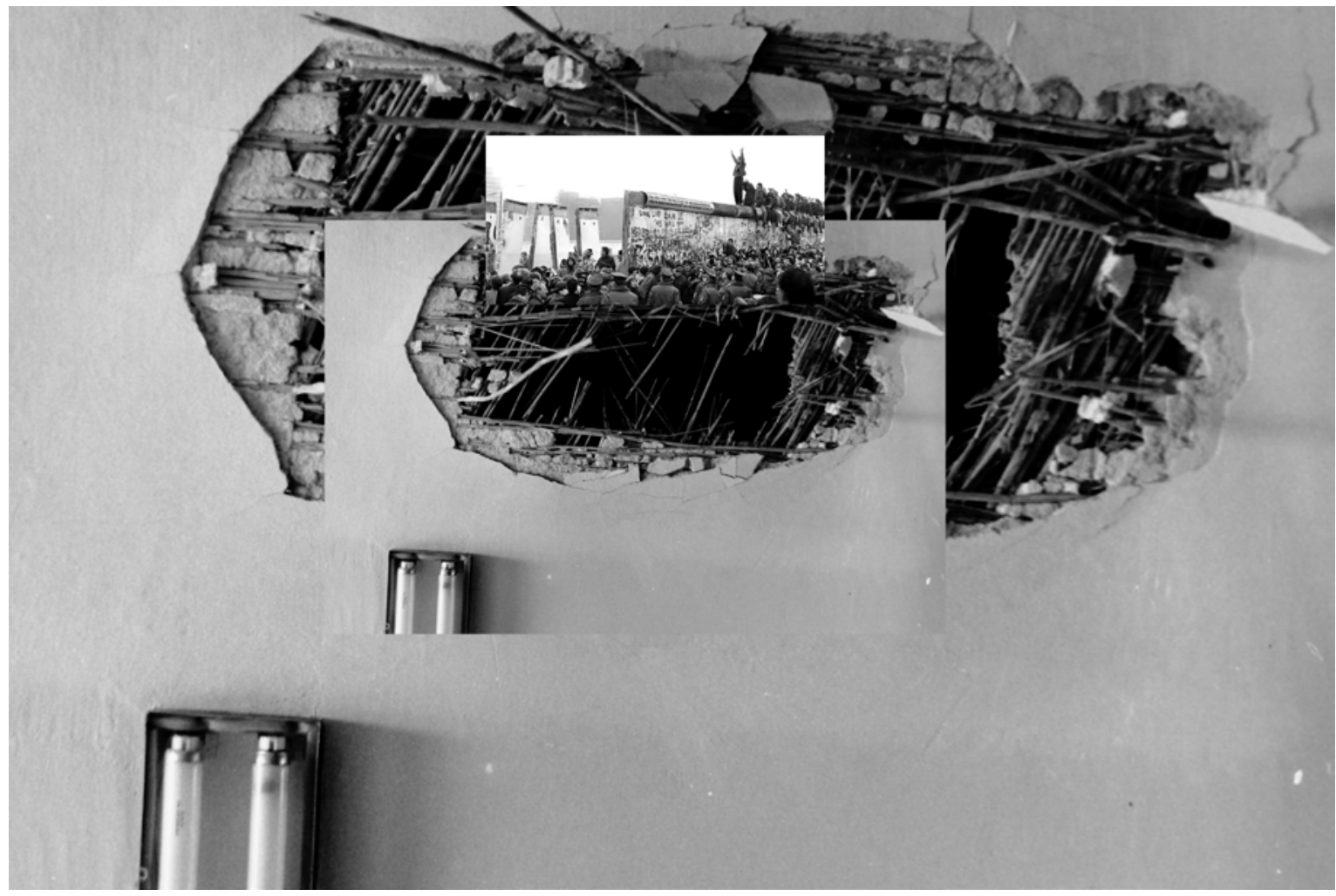


buildings and trees. Visitors still take selfies with the remaining segments of the wall serving as background, layers upon layers of graffiti, mostly forlorn. With time, fragments of the wall were scattered - larger pieces were donated as memorials, smaller bits carried in pockets - all over the world. Fragments of an unimaginable, and yet conceivable whole.

\section{Action 1 (figures 1 and 2)}

The picture shows an opening that was cut through concrete, although its main subject is located elsewhere. There is a sea of people gathered next to the wall, some are sitting in a row with their feet dangling to the either side. A man, first in line, stood up and rose his hands towards the sky. The photographers noticed the disruption within their field of vision, and began shooting. One captured the man making the victory sign with both hands; this was a reoccurring gesture throughout those days and months. In Barthian' fashion, my eye drifts back to another disturbance, the cut delimiting the section of the wall he'd climbed, an apparently seamless, surgical cut. The surface is pristine on one side and overflowing with graffiti on the other. It strikes me that the top of the wall is rounded off, which must have made it somewhat difficult to stand on. A balancing act. Should he fall, the man might have relied on those below to catch him, a concert-like crowd surfing fall. His moment of elation was captured by several photographers that day. It is likely that the man was aware of their presence beforehand. Was he performing for or with the camera? If that were that the case, could he be perceived as disingenuous? A range of possibilities ensues. Had he not performed for the camera, would this coincidence - the sync between the gesture and camera - be perceived as more authentic? Further details are revealed, depending on the photographer's position in relation to the event. A slight change in angle, and the view alters, the field of view broadens. Some images show men in uniforms, possibly former guards and the police. They might be monitoring the crowd, although they seem at ease. Could they have come in order to join in?

\section{Situation 1 (figure 3)}

People, the crowd, the mass, overflowing, flooding the frame. In the foreground people are climbing on top of a truck, barely holding on. At the back they are holding up a banner "Jos Tiranul," (down with the tyrant). In the background people are waving flags, some with the emblem of the Socialist Republic of Romania cut out. Even though this is a simple gesture, the empty circle incorporates the gravity of those days. The signifier is hollowed out into an improvised memorial, while the actions it references are yet to fully unfold. Everyone seems to be looking at the camera, or in its general direction. The picture was taken in Bucharest on December 22, 1989, by the photojournalist
Radu Sigheti. Following days of protests, the protesters barged into the headquarters of the Party's Central Committee, forcing Nicolae and Elena Ceausescu to flee. The square in which they gathered was later renamed Revolution Square. That same day, the protesters took over the national TV station, wherein the regime produced its daily broadcast. They entered the scene, and began addressing the people, live. Coincidentally, merely a few days earlier, the moment when the revolution erupted in Bucharest was also transmitted live. The nationwide transmission of Ceausescu's speech was suddenly interrupted due to unexpected movements within the audience that had assembled precisely in the same square wherefrom the dictator would be ousted on December 22. Harun Farocki and Andrei Ujica's film Videograms of a Revolution deconstructs that situation brilliantly, analysing the movements of - and exchanges between - the protagonist, camera and crowd. As a rejoinder to Gil Scott-Heron's mantra one might add that within that moment the revolution was both televised and live.

\section{Action 2 (figures 4, 5 and 6)}

Timing. The Romanian revolution was set into action like clockwork. The domino effect of the crowd, click-clack, all the pieces have fallen into a considerable, yet calculated disarray. The Internet and social media appear to have extended the possibilities for unrest. Nonetheless, in the aftermath of Tahrir, change seems to require more time. Enough time for the crowd to assemble online and descend into the square. I am reminded of Josef Koudelka's cinematic capture of Prague at the moment that immediately preceded the entry of Soviet tanks. The silence is palpable, embossed in the negative, engrained in the print. I am also reminded of Robert Capa's sensational photograph of a Republican soldier taken at Cerro Muriano, on or around September 5, 1936, during the Spanish Civil War. Under the subheading "comment ils sont tombés" (how they have fallen), the original photo-essay included the picture alongside an image of another soldier, tumbling to his death, although captured much closer to the ground (Vu magazine 1936). Despite the considerable debate as to its veracity (Was it taken at the exact moment of death? To what extent was it staged?), The Falling Man remains one of the most oft remembered and quoted photographs in history. Perhaps this is due to its workings on an emotional level, the sense it gives of being that close to a moment as private as another person's death. It is a final, terminal picture, yet a provoking one. It may have even stirred strong emotions at the time, whether in Spain or abroad, leading readers to ponder the futility of war, or the unavoidability of death. In my mind this photograph summons another, this time from a conflict that took place almost half a century later. It was taken in Nicaragua by photographer Susan Meiselas, in the summer of 1979, during the final days of the popular armed insurgence led by the Sandinista movement against the dictatorship of Anastasio Somoza 


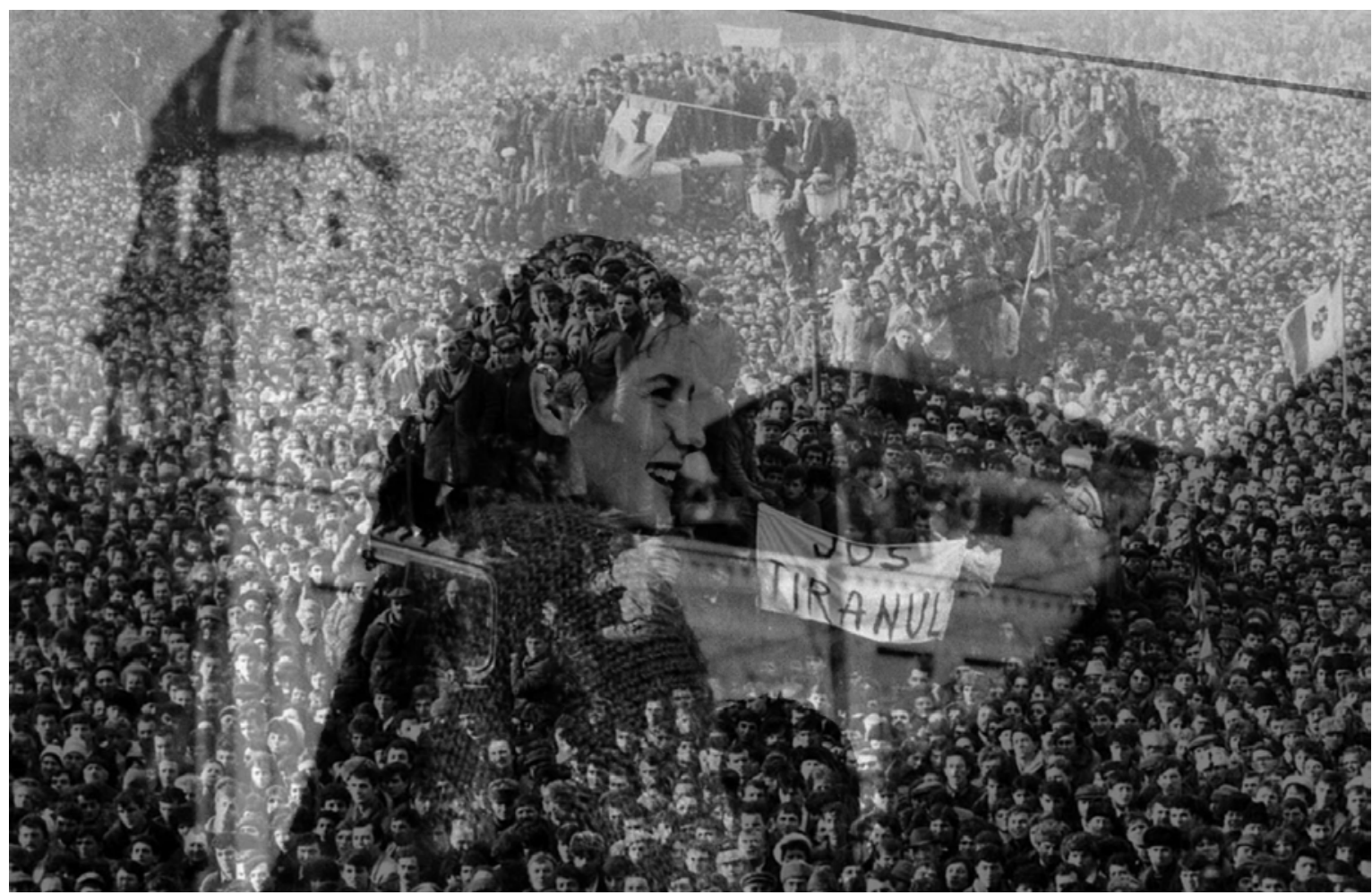

Figure 4

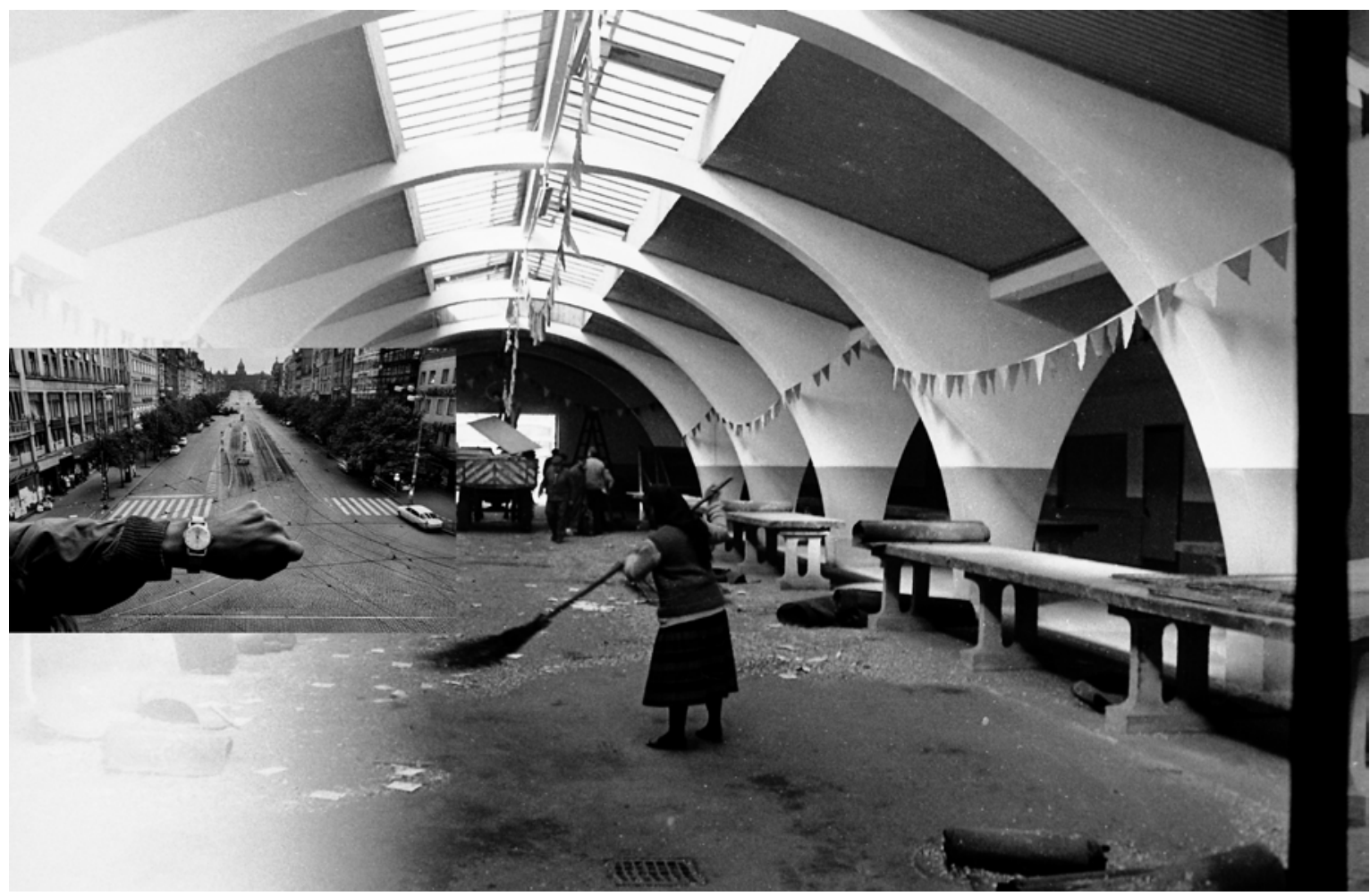


Debayle. It is an iconic image from the Sandinista revolution, colloquially referred to as the "Molotov Man." The composition mirrors Capa's. Eerie similarities can be found in the details: the position of the weapon, the body, and the way in which movement is captured, frozen in time. However, as the Republican soldier recoils, the Molotov Man thrusts forward. One's fall is reciprocated by another's leap ahead.

\section{Situation 2}

In April 2018, the streets of Managua, Nicaragua erupted in protest once more. Scenes from the 1978-79 insurgence seemed to be played back in real time. Many observers described the experience by referencing photographs from the past, including the "Molotov Man." A man too young to remember the insurrection or the ensuring revolution, which lasted throughout the eighties, said that during those tumultuous months between April and July: "it was as if I was looking through a window into the past." Images reverberate, they bridge unbridgeable distances though both, space and time. I notice a portrait of a smiling Nicaraguan woman wearing a T-shirt that reads "civil disobedience." She reminds me of the young Romanian men and women I saw on TV when I was a child. It is powerful to think of such gestures of disobedience as connected, even if they are connected in ways that are anything but obvious or apparent. The space of reflection that has fallen in-between, is a place to claim as one's own. As if there was a lineage of sorts, a repertoire that was made accessible to us all. The Molotov Man rises from amongst my childhood streets, a stranger falls asleep, dreaming of The Falling Man. These are shared imaginaries to which we could all potentially - return.

\section{Sources}

Didi-Huberman G. 2016. Soulèvements. With contributions by Nicole Brenez, et. al Paris: Livres d'Art, Gallimard/Jeu de Paume.

Pink Floyd. 1973. "Us and Them." The Dark Side of the Moon.

Vu magazine. 1936. “La Guerre Civile en Espagne.” September 23, 1936.

\section{Short biography}

Ileana L. Selejan is a Research Associate at the Department of Anthropology at the University College London, where she is a part of the European Research Council (ERC) funded project 'Citizens of Photography: The Camera and the Political Imagination' (Grant no. 695283), and an Associate Lecturer at the Central Saint Martins, University of the Arts, London. She was previously the Linda Wyatt Gruber'66 Curatorial Fellow in Photography at The Davis Museum at Wellesley College where she curated the exhibition 'Charlotte Brooks at LOOK: 1951-1971'. She received her PhD in Art History from the Institute of Fine Arts, New York University, and was granted the 2012-13 Joan and Stanford Alexander Award from the Museum of Fine Arts Houston for her dissertation research in Nicaragua. As an adjunct instructor, she taught at the Photography and Imaging Department at Tisch School of the Arts, at the Art History Department at NYU, at the Parsons School of Design, and at the Fine Arts Department at West University, Timisoara, Romania. 


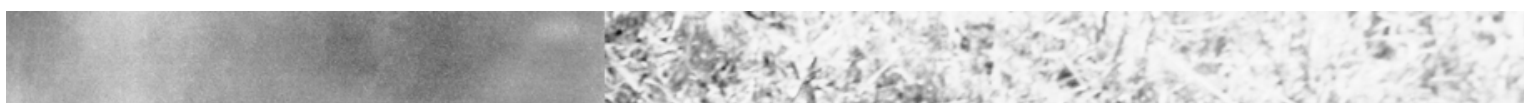

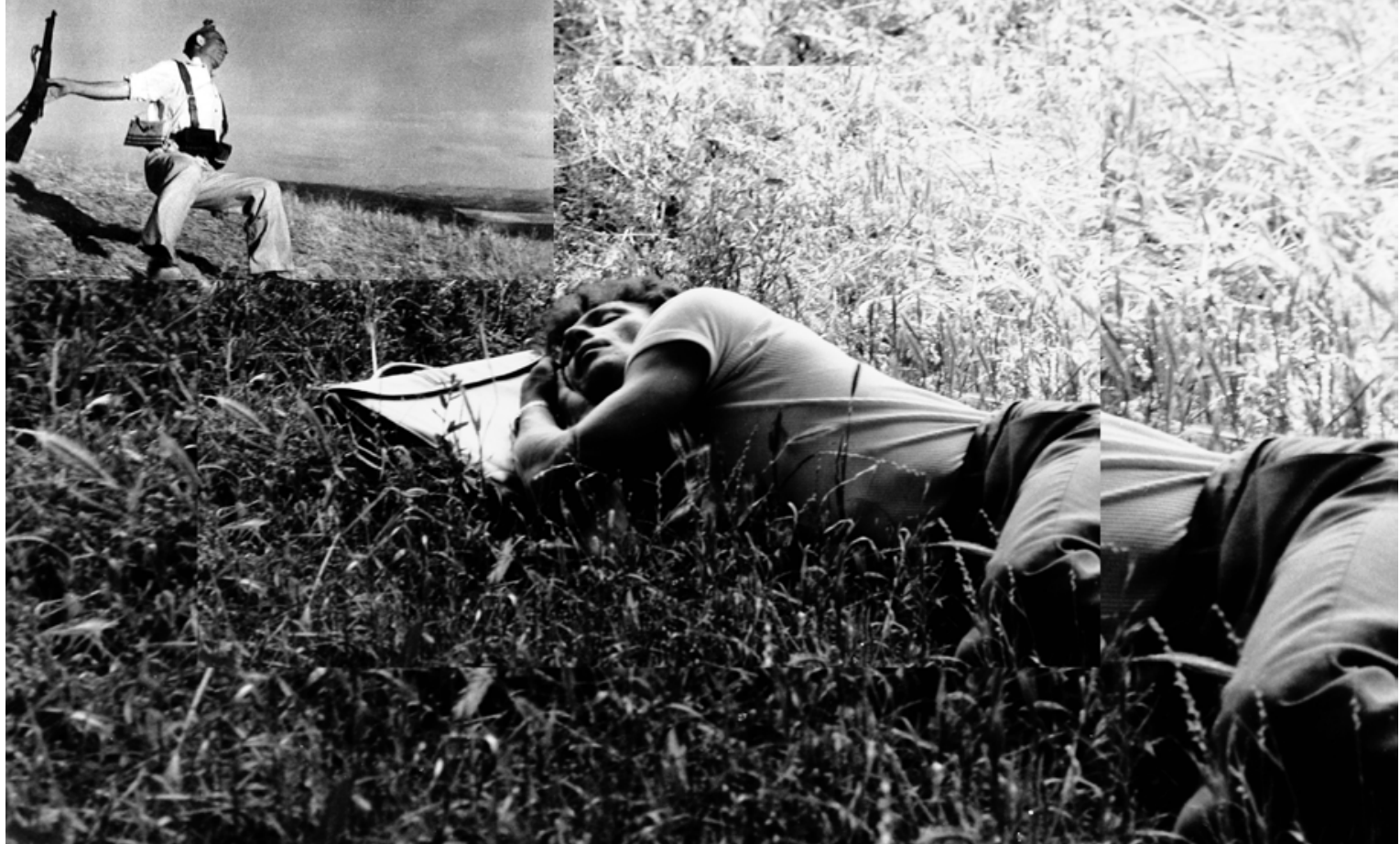

Figure 6

$\mathbb{A} \mathbb{N} \mathbb{I} \mathbb{\mathbb { A }} \mathbb{R} \mathbb{A} \mathbb{I}$

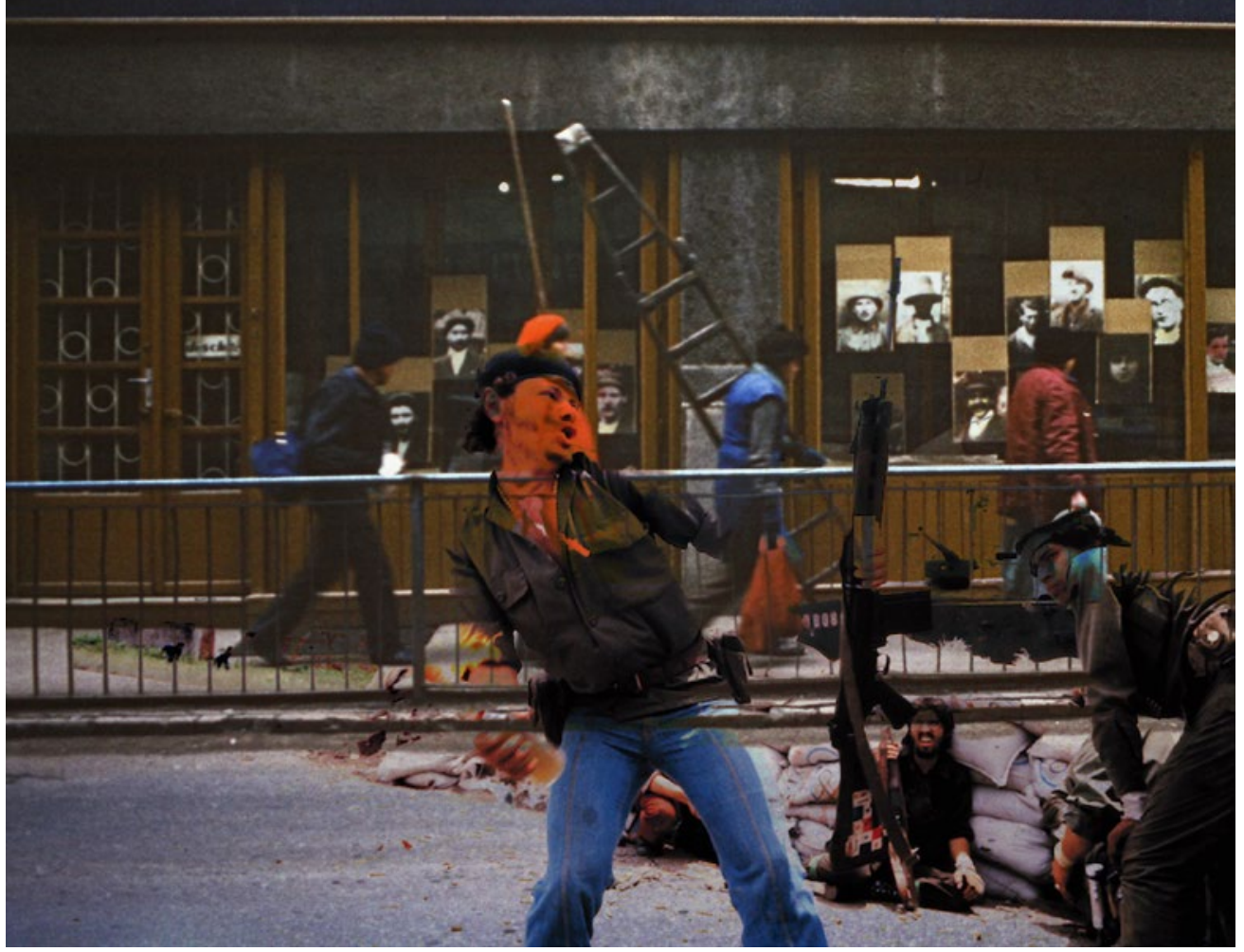




\title{
GALERIJA FOTOGRAFIJA
}

\section{BOOKSTORE AND GALLERY FOTOGRAFIJA}

Photographic literature, overviews,

photobooks, magazines, exhibition catalogues ...

\author{
Levstikov trg 7, Ljubljana, Slovenia
}

www.galerijafotografija.si

MEMBRANA Vol. 4, no. 2 / 2019 • ISSN 2463-8501 • publisher: Membrana, Maurerjeva 8, 1000 Ljubljana • tel.: +386 (0) 31777959 • email: info@membrana. org • editors: Jan Babnik (editor-in-chief, independent researcher), Ilija T. Tomanić (Faculty of Social Sciences, University of Ljubljana) • editorial board: dr. Mark Curran (Dublin Institute of Technology, Ireland; Freie Universität Berlin, Germany), dr. Ana Peraica (independent researcher, educator, Croatia), dr. Witold Kanicki (UAP Poznań, Poland), Miha Colner (International Centre for Graphic Arts, MGLC, Ljubljana, Slovenia), Lenart Kučić (independent journalist, Pod črto, Slovenia), Emina Djukić (University of Ljubljana, Slovenia), Jasna Jernejšek (independent researcher, curator, Slovenia), dr. Asko Lehmuskallio (University of Tampere, Finland), Devon Schiller (independent researcher, USA), dr. Robert Hariman (Northwestern University, USA), dr. Murat Germen (Sabanci University, Istanbul), Alisha Sett (Jnanapravaha Mumbai, India), dr. Andreia Alves De Oliveira • contributors: Alex Beldea, Ayse Lucie Batur, Gabriel Uchida, Ileana L. Selejan, Ioan Daniel Mihalcea, Maria Paschalidou, Iza Pevec, Karin Becker, Louise M. Hisayasu, Murat Germen, Nataša llec, Stephen Snyder • proofreading: Tom Smith, Sonja Benčina • image \& projects contributors: Activestills, Alex Beldea, Anat Saragusti, Andrei Iliescu, Anne Paq, Călin Man, Füsun Turcan Elmaso lu, Gabriel Uchida, Janna Tamimi, Michel Euler, Murat Germen, Maria Paschalidou, Stephen Snyder • design: Primož Pislak • printing: Cicero • print run: 400 • all images and texts @Membrana, except when noted otherwise • editorial and back cover photograph: Murat Germen: Freedom Day: No Turn to Right, 2013, cropped, courtesy of the author. 
